\title{
Protective effect and mechanism of ginsenoside Rg1 on carbon tetrachloride-induced acute liver injury
}

\author{
BENQUAN QI $^{1 *}$, SUZHI ZHANG ${ }^{2 *}$, DAOHUA GUO ${ }^{3}$, SANXING GUO $^{4}$, XIAODONG JIANG ${ }^{3}$ and XILING ZHU ${ }^{3}$ \\ ${ }^{1}$ Department of Emergency Internal Medicine, The First Affiliated Hospital of Bengbu Medical College, Bengbu, \\ Anhui 233004; ${ }^{2}$ Department of Pharmacology, Zhongshan School of Medicine, Sun Yat-sen University, Guangzhou, \\ Guangdong 510080; ${ }^{3}$ Department of Pharmacy, The First Affiliated Hospital of Bengbu Medical College, \\ Bengbu, Anhui 233004, P.R. China; ${ }^{4}$ Centre for Biomedicine and Medical Technology Mannheim (CBTM), \\ Medical Faculty Mannheim, University of Heidelberg, D-68167 Mannheim, Germany
}

Received March 31, 2016; Accepted March 10, 2017

DOI: $10.3892 / \mathrm{mmr} .2017 .6920$

\begin{abstract}
Liver injury is a common pathological state in various types of liver disease; severe or persistent liver damage is the basis of hepatic failure. Ginsenoside Rg1 (Rg1), one of the primary active ingredients of ginseng, has been reported to reduce concanalin A-induced hepatitis and protect against lipopolysaccharide- and galactosamine-induced liver injury. However, the underlying protective mechanism of Rg1 in acute liver injury remains unclear. In the present study, a carbon tetrachloride $\left(\mathrm{CCl}_{4}\right)$-induced acute liver injury model was established, and the protective effect of $\mathrm{Rg} 1$ on $\mathrm{CCl}_{4}$-induced acute liver injury was demonstrated in cell culture and animal experimental systems. Further investigation of the mechanisms demonstrated that pretreatment with Rg1 reduced elevated levels of alanine aminotransferase and aspartate aminotransferase, enhanced the antioxidant activity of superoxide dismutase (SOD) and decreased malondialdehyde (MDA) content. Experiments in vitro demonstrated that Rg1 decreased p65 expression and inhibited nuclear factor (NF)- $\mathrm{B}$ activity. In addition to the effect of $\mathrm{Rg} 1$, an $\mathrm{NF}-\kappa \mathrm{B}$ inhibitor promoted cell survival, enhanced SOD activity and reduced MDA level. It was observed through in vivo experiments that pretreatment with Rg1 inhibited NF- $\kappa$ B expression and activity in Kupffer cells and reduced the serum levels of tumor necrosis factor- $\alpha$ and interleukin- 6 . In conclusion, the results of the present study indicated that pretreatment with $\mathrm{Rg} 1$ may rescue $\mathrm{CCl}_{4}$-induced
\end{abstract}

Correspondence to: Professor Xiaodong Jiang or Miss. Xiling Zhu, Department of Pharmacy, The First Affiliated Hospital of Bengbu Medical College, 287 Changhuai Road, Bengbu, Anhui 233004, P.R. China

E-mail: 815926374@qq.com

E-mail: 345056979@qq.com

*Contributed equally

Key words: ginsenoside Rg1, nuclear factor- $\kappa \mathrm{B}$, acute liver injury, oxidative stress, inflammatory response acute liver injury in vivo and in vitro through inhibition of $\mathrm{NF}-\kappa \mathrm{B}$ activity, to restore the anti-oxidative defense system and down-regulate pro-inflammatory signaling pathways. The present observations provide a theoretical foundation for the clinical application of $\operatorname{Rg} 1$ therapy in acute liver injury.

\section{Introduction}

The liver, one of the largest organs in the human body, serves a vital role in the metabolism of carbohydrates, lipids and proteins, the regulation of immune responses, and the clearance of toxins and pathogens $(1,2)$. The liver is frequently exposed to various insults, which may cause cell swelling, degeneration, necrosis, apoptosis, hepatic fibrosis and dysfunction. As the fifth most common cause of mortality following heart disease, stroke, lung disease and cancer (3), the rates of liver disease, unlike other major causes of mortality, are increasing (4). However, the available synthetic drugs, including interferon and corticosteroids, are expensive and may present the risk of adverse effects (5). Therefore, treating liver disease with alternative medicine seems attractive, as a number of medicinal plants, which have been traditionally used for centuries, are accessible and appear to exhibit decreased toxicity (6). Ginsenoside $\mathrm{Rg} 1(\mathrm{Rg} 1)$ is one of the primary active ingredients in ginseng, and possesses the potential to protect cardiovascular and nervous system activity, as well as anti-tumor, anti-fatigue and anti-aging capabilities (7-9). Komatsu et al (10) demonstrated that Rg1 protected against lipopolysaccharide- and galactosamine-induced hepatic damage. Additionally, Cao et al (11) reported that $\mathrm{Rg} 1$ reduced concanavalin A-induced hepatitis in mice through inhibition of cytokine secretion and lymphocyte infiltration. Pretreatment with Rg1 protected mice from IR-induced liver injury by reducing hepatocellular apoptosis and inhibiting inflammatory responses (12). The present study aimed to investigate the effect and underlying mechanism of $\mathrm{Rg} 1$ on carbon tetrachloride $\left(\mathrm{CCl}_{4}\right)$-induced acute liver injury in vitro and in vivo, and to provide the theoretical foundation of the clinical application of $\operatorname{Rg} 1$ in acute liver injury.

Liver injury is a common pathological state in various types of liver disease; severe or persistent liver damage is the basis of hepatic failure (13). $\mathrm{CCl}_{4}$ is a commonly-applied 
chemical substance which may induce acute and chronic liver injury in animal models. It is well known that following activation by cytochrome $\mathrm{P} 450$ metabolism in the liver, $\mathrm{CCl}_{4}$ generates numerous free radicals and reactive oxygen species which cause oxidative stress. These species cause membrane lipid peroxidation and bind protein macromolecules through covalent linkage, ultimately leading to interference with protein function, the destruction of cell membrane structure, increased permeability of the cell membrane, leakage of liver enzymes and liver cell death $(14,15)$.

Nuclear factor $(\mathrm{NF})-\kappa \mathrm{B}$, a transcription factor known to regulate inflammatory responses in a number of cell types (16), was demonstrated to be involved in a variety of types of liver injuries (17-21). Liu et al (9) observed that Rg1 inhibited $\mathrm{NF}-\kappa \mathrm{B}$ activity to protect against $\mathrm{H}_{2} \mathrm{O}_{2}$-induced cell death in rat adrenal pheochromocytoma $\mathrm{PC} 12$ cells; additionally, the study of Tao et al (12) demonstrated that pretreatment with Rg1 protected mice from ionizing radiation-induced liver injury by reducing hepatocellular apoptosis and inhibiting inflammatory responses, in part via the $\mathrm{NF}-\kappa \mathrm{B}$ signaling pathway. However, the effect of $\mathrm{Rg} 1$ on $\mathrm{CCl}_{4}$-induced acute liver injury and its mechanism, including the association between $\mathrm{Rg} 1$ and $\mathrm{NF}-\kappa \mathrm{B}$, have not been systematically studied. The present study demonstrated that pretreatment with $\mathrm{Rg} 1$ may protect against $\mathrm{CCl}_{4}$-induced acute liver injury in vivo and in vitro, and the protective effect was associated with inhibition of the $N F-\kappa B$ signaling pathway to restore the anti-oxidative defense system. A reduction in elevated alanine aminotransferase (ALT) and aspartate aminotransferase (AST) levels was observed, as well as the inhibition of lipid peroxidation expressed as enhancement in superoxide dismutase (SOD) activity and a decrease in malondialdehyde (MDA) expression. Attenuation of inflammatory responses expressed as a decrease in serum tumor necrosis factor (TNF)- $\alpha$ and interleukin (IL)-6 levels was also observed.

\section{Materials and methods}

Reagents. $\mathrm{Rg} 1\left(\mathrm{C}_{42} \mathrm{H}_{72} \mathrm{O}_{14}\right)$ was obtained from Shanghai YaJi Biotechnology Co., Ltd. (Shanghai, China; cat. no. MUST-11041201); $\mathrm{CCl}_{4}$ was purchased from Shanghai ShenXiang Chemical Reagent Co., Ltd. (Shanghai, China; cat. no. 20090510); minimum essential medium with Earle's balanced salts (MEM-EBSS) was purchased from Gibco (Thermo Fisher Scientific, Inc., Waltham, MA, USA); fetal bovine serum (FBS) was from Hangzhou Evergreen Biological Material Co., Ltd. (Hangzhou, China); penicillin and streptomycin were from North China Pharmaceutical Co., Ltd. (Shijiazhuang, China); dimethyl sulfoxide (DMSO) was from Beijing YiLi Fine Chemicals Co., Ltd. (Beijing, China); NF- $\mathrm{B}$ p65 antibody (rabbit anti-mouse) was from Sigma-Aldrich (Merck KGaA, Darmstadt, Germany; cat. no. SAB4502609); bicinchoninic acid protein concentration assay kit was from Beijing Biosynthesis Biotechnology Co., Ltd. (Beijing, China); NF- $\kappa$ B electrophoretic mobility shift assay (EMSA) kit (cat. no. 20148) was from Thermo Fisher Scientific, Inc.; biotin-labeled NF- $\kappa \mathrm{B}$ probes (oligonucleotide sequences: 3'-TCAACTCCCCTGAAAGGGTCCG-5' and 5'-AGTTGAGGGGACTTTCCCAGGC-3') were purchased from Shanghai Sangon Biological Engineering Co., Ltd.
(Shanghai, China); TNF- $\alpha$ (cat. no. MTA000B) and IL-6 (cat. no. M6000B) ELISA kits were from R\&D Systems, Inc. (Minneapolis, MN, USA); and ALT (cat. no. C009-3), AST (cat. no. C010-3), SOD (cat. no. A001-2), and MDA (cat. no. A003-1) kits were from Nanjing JianCheng Bioengineering Institute (Nanjing, China).

$\mathrm{CCl}_{4}$ injury mouse model. $\mathrm{A} \mathrm{CCl}_{4}$-induced acute liver injury model of mice was established as described by Li et al (22). Male Kunming mice ( $20 \pm 2 \mathrm{~g} ; \mathrm{n}=60)$ were purchased from the Experimental Animal Center of Anhui Medical University [animal license no. SCXK (Anhui) 2011-002; Hefei, China]. The facilities and the protocol for these experiments were consistent with the regulations of animal use for biomedical experiments as issued by the Ministry of Science and Technology of China and were also approved by the animal ethics committee of Bengbu Medical College (Bengbu, China). The mice were kept in the dark and had free access to standard chow and water. Following 3 days of adaptive feedings, the 60 mice were randomly divided into five groups: i) Control group [olive oil (Hong Rui Men; Jiangxi Hongrui Oil Food Co. Ltd., Nanchang, China), $0.1 \mathrm{ml} / 10 \mathrm{~g}$ body weight]; ii) model group $\left(\mathrm{CCl}_{4}, 0.1 \mathrm{ml} / 10 \mathrm{~g}\right.$ body weight), iii) low Rg1 group ( $\mathrm{Rg} 1,10 \mathrm{mg} / \mathrm{kg}$ body weight; $\mathrm{CCl}_{4} 0.1 \mathrm{ml} / 10 \mathrm{~g}$ body weight), iv) middle $\mathrm{Rg} 1$ group $\left(\mathrm{Rg} 1,20 \mathrm{mg} / \mathrm{kg} ; \mathrm{CCl}_{4} 0.1 \mathrm{ml} / 10 \mathrm{~g}\right.$ body weight), v) high $\mathrm{Rg} 1$ group ( $\mathrm{Rg} 1,40 \mathrm{mg} / \mathrm{kg} ; \mathrm{CCl}_{4} 0.1 \mathrm{ml} / 10 \mathrm{~g}$ body weight). Oral doses of $\operatorname{Rg} 1$ were administered once a day for 7 days and all groups, except the control group, were intraperitoneally injected with $0.1 \% \mathrm{CCl}_{4}$ in olive oil (v/v) $2 \mathrm{~h}$ subsequent to the last dose of $\mathrm{Rg} 1$ in order to induce acute liver injury, while the mice in control group were injected with an equal volume of olive oil. All mice were fasted and had free access to water overnight. The blood was obtained from the orbital sinus, centrifuged at $268.3 \mathrm{x} \mathrm{g}$ for $5 \mathrm{~min}$ at $37^{\circ} \mathrm{C}$ and prepared for ALT and AST content detection. The liver was rapidly removed subsequent to the mice being sacrificed, and was rinsed three times with saline to remove blood. The left lobe of the liver was prepared for hematoxylin and eosin (H\&E) staining and the right lobe of the liver for SOD, MDA, TNF- $\alpha$ and IL- 6 content detection.

Isolation and purification of Kupfer cells. Following intraperitoneal injection with $\mathrm{CCl}_{4}$ olive oil solution into mice for $1 \mathrm{~h}$, Kupffer cells from each group of animals were collected $(n=4)$. Hepatic perfusion and digestion was performed according to the method described by Fukada et al (23). Following intraperitoneal injection with $\mathrm{CCl}_{4}$ olive oil solution into the mouse for $1 \mathrm{~h}$, the mouse was anesthetized with chloral hydrate (5\% chloral hydrate, $0.1 \mathrm{ml} / 10 \mathrm{~g}$ body weight) and the abdomen opened to confirm the location of the portal vein. The portal vein was cannulated with a $22 \mathrm{G}$ catheter, $\sim 1 \mathrm{~cm}$ away from the hepatic portal with $0.8-\mathrm{cm}$ insertion and an arterial clamp. The liver was perfused with the first infusion, composed of $\mathrm{NaCl}(137 \mathrm{mmol} / \mathrm{l}), \mathrm{KCl}(2.68 \mathrm{mmol} / \mathrm{l}), \mathrm{Na}_{2} \mathrm{HPO}_{4} \cdot 12 \mathrm{H}_{2} \mathrm{O}$ (0.7 mmol/l), HEPES (10 mmol/l), glucose (10 mmol/l), EDTA- $\mathrm{Na}_{2}(0.5 \mathrm{mmol} / \mathrm{l})$ and heparin $(2,000 \mathrm{U} / \mathrm{l}), \mathrm{pH} 7.4$, until the liver volume had expanded to $\sim 2 \mathrm{X}$ the original volume and a slight white color was observed. The inferior vena cava was subsequently cut. Finger pressure was applied to the segments, and they were intermittently opened to enlarge and retract the 
liver alternately following liver retraction. When the liver had turned white, with 15 min reperfusion, the liver was removed to a sterile petri dish (reserving the portal vein catheterization). Perfusion of the liver was continued with the second infusion, composed of $\mathrm{NaCl}(137 \mathrm{mmol} / \mathrm{l}), \mathrm{KCl}(2.68 \mathrm{mmol} / \mathrm{l})$, $\mathrm{Na}_{2} \mathrm{HPO}_{4} \cdot 12 \mathrm{H}_{2} \mathrm{O}(0.7 \mathrm{mmol} / \mathrm{l})$, HEPES $(10 \mathrm{mmol} / \mathrm{l})$, glucose (10 mmol/l), $\mathrm{CaCl}_{2}(5 \mathrm{mmol} / \mathrm{l})$ and collagenase IV $(0.05 \%)$, $\mathrm{pH} 7.4$, for $\sim 15 \mathrm{~min}$, until the liver became soft and structural collapse was observed. Liver cells were scattered to form a cell suspension using stirring and percussion with a dropper.

For the isolation of Kupffer cells, the method described by Fukada et al (23) and Smedsrød and Pertoft (24) in 1985 was employed and improved. The cell suspension was subjected to low-speed centrifugation $\left(16.7 \mathrm{x} \mathrm{g}\right.$ for $3 \mathrm{~min}$ at $\left.4^{\circ} \mathrm{C}\right)$ and the supernatant was removed prior to the precipitate being resuspended in $10 \mathrm{ml}$ PBS. Subsequently, $15 \mathrm{ml} 50 \%$ Percoll liquid (Shanghai Xinyu Biotechnology Co., Ltd., Shanghai, China) was added into a new tube and $20 \mathrm{ml} \mathrm{25 \%}$ Percoll liquid was carefully added along the tube wall, followed by $10 \mathrm{ml}$ cell suspension. Following centrifugation at $268.3 \mathrm{x} \mathrm{g}$ for $15 \mathrm{~min}$ at $4^{\circ} \mathrm{C}$, four apparent partitions were observed: From top to bottom these were cell debris, non-parenchymal cells enriched in endothelial cells, Kupffer cells and red cells, which precipitated at the bottom of the tube. The Kupffer cells were collected, $15 \mathrm{ml}$, and were diluted with $15 \mathrm{ml}$ PBS. Following centrifugation at $268.3 \mathrm{x}$ g for $10 \mathrm{~min}$ at $4^{\circ} \mathrm{C}$, the precipitate was resuspended in culture medium.

Subsequently, purification of Kupffer cells was performed; the survival rate of the cells was $>90 \%$ as observed with Trypan blue staining $\left(3 \mathrm{~min}\right.$ at $\left.4^{\circ} \mathrm{C}\right)$. The cells were counted and the concentration adjusted to $2 \times 10^{6} / \mathrm{ml}$, and $1 \mathrm{ml}$ cell suspension/well was seeded on 12-well culture plates. Following incubation for $2 \mathrm{~h}$ at $37^{\circ} \mathrm{C}$ in an atmosphere of $5 \% \mathrm{CO}_{2}$ in air, the cells were gently washed with fresh culture medium, and the adherent cells were considered to be Kupffer cells. Cell culture was continued, with the medium being changed every 2-3 days.

$H \& E$ staining of liver tissue. The left lobe of the removed liver was fixed in neutral formalin, paraffin-embedded and sliced. A $2.0 \times 2.0 \times 0.3 \mathrm{~cm}$ block of tissue was selected from the same site of each mouse, washed with saline and placed in $10 \%$ neutral formalin buffer at $37^{\circ} \mathrm{C}$. Following dehydration, the blocks were wax embedded, sliced into 5- $\mu \mathrm{m}$ sections, dewaxed, $\mathrm{H} \& \mathrm{E}$ stained for $5 \mathrm{~min}$ at $37^{\circ} \mathrm{C}$, dehydrated, and mounted in neutral balsam. The tissues were observed using an optical microscope in the Department of Pathology at the First Affiliated Hospital of Bengbu Medical College and images of morphological changes were captured using a light microscope (magnification, $\mathrm{x} 100)$.

Determination of serum ALT and AST content. The blood obtained from the orbital sinus was centrifuged at 1,341.6 x g at $4^{\circ} \mathrm{C}$ for $10 \mathrm{~min}$ and the serum content of ALT and AST was measured in accordance with the manufacturer's protocol of the ALT and AST activity kits.

Determination of liver SOD and MDA content. The right liver lobes of the sacrificed mice were cut and weighed and $400 \mathrm{mg}$ liver tissue was combined with saline (1:9 v/v) and crushed on ice using a glass homogenizer. The homogenized solutions were centrifuged at $1,341.6 \mathrm{x}$ g at $4^{\circ} \mathrm{C}$ for $15 \mathrm{~min}$, and the resulting $10 \%$ liver homogenate supernatants were measured for SOD and MDA content in accordance with the manufacturer's protocol for the kits.

Determination of liver TNF- $\alpha$, IL-6 levels using ELISA. The remainder of the right lobes of the livers were cut and weighed, and $400 \mathrm{mg}$ was combined with saline (1:9 v/v) and crushed on ice using a glass homogenizer. The homogenates were centrifuged at $1,341.6 \mathrm{x}$ g at $4^{\circ} \mathrm{C}$ for $15 \mathrm{~min}$, and the optical density of the supernatant was detected at $450 \mathrm{~nm}$ and compared to the TNF- $\alpha$ or IL- 6 standard curve in accordance with the manufacturer's protocol for the kit.

$\mathrm{LO}_{2}$ cell culture. $\mathrm{LO}_{2}$ human normal liver cells, donated by the College of Pharmacy, Sun Yat-sen University, were maintained in MEM-EBSS containing $10 \% \mathrm{FBS}$ and $1 \%$ penicillin/streptomycin at $37^{\circ} \mathrm{C}$ in an atmosphere of $5 \% \mathrm{CO}_{2}$ in air. The cells were trypsinized and diluted to $5 \times 10^{4}$ cells $/ \mathrm{ml}$ in the logarithmic phase prior to the experiment.

$\mathrm{CCl}_{4}$ injury cell model. The viability of $\mathrm{LO}_{2}$ cells incubated with $\mathrm{CCl}_{4}$ or Rg1 was measured by MTT assay. A total of $5 \times 10^{3}$ cells/well were seeded into 96 -well plates for $24 \mathrm{~h}$ and then increasing concentrations of $\mathrm{CCl}_{4}$ in normal saline $(2.5,5$, 10,20 and $40 \mathrm{mM}$ ) were added for $3 \mathrm{~h}$. Each group was plated in triplicate and normal saline was used as control group. For $\mathrm{Rg} 1$ treatment, $0.1,1$ and $10 \mu \mathrm{M} \mathrm{Rg} 1$ was added to $\mathrm{LO}_{2}$ cells. After $21 \mathrm{~h}, 20 \mathrm{mM} \mathrm{CCl}_{4}$ (the most appropriate concentration from the liver cell injury model) was added and incubated for a further $3 \mathrm{~h}$. An NF- $\kappa \mathrm{B}$ inhibitor [caffeic acid phenethyl ester (CAPE); $25 \mu \mathrm{M}$ for $2 \mathrm{~h}$ ] was additionally assessed. Subsequently, $20 \mu \mathrm{l}$ MTT (Shanghai Gefan Biotechnology Co., Ltd., Shanghai, China; $5 \mathrm{mg} / \mathrm{ml}$ ) was added to each well for a further $4 \mathrm{~h}$, the supernatants were carefully discarded and $150 \mu \mathrm{l}$ DMSO was added to each well in order to dissolve the crystals. The absorbance at $570 \mathrm{~nm}$ was measured and the cell viability was calculated as follows: Survival rate $=$ (absorbance of treated group-absorbance of blank group)/(absorbance of control group-absorbance of blank group).

Determination of cell AST, ALT levels, SOD activity and MDA content. A total of $5 \times 10^{4} \mathrm{LO}_{2}$ cells/well were seeded into 24-well plates and incubated at $37^{\circ} \mathrm{C}$ for $24 \mathrm{~h}$. Treatment with $\operatorname{Rg} 1$ at $0.1,1$ and $10 \mu \mathrm{M}$ was performed for $21 \mathrm{~h}$, and $20 \mathrm{mM} \mathrm{CCl}_{4}$ was added for a further $3 \mathrm{~h}$. The supernatant was collected, and AST and ALT expression levels, SOD activity and MDA, content were measured according to the manufacturer's protocols.

Determination of cell $N F-\kappa B$ activity using EMSA. The $\mathrm{NF}-\kappa \mathrm{B}$ activity in $\mathrm{LO}_{2}$ and Kupffer cells was detected by EMSA as described by Li et al (25). The nuclear proteins were incubated in $1 \mathrm{X}$ binding buffer $(50 \mathrm{ng} / \mu 1$ poly (deoxyinosinic-deoxycytidylic), $0.05 \% \mathrm{NP}-40,5 \mathrm{mM} \mathrm{MgCl} 2,50 \mathrm{mM}$ $\mathrm{KCl}, 2.5 \%$ glycerol, and ultra-pure $\mathrm{H}_{2} \mathrm{O}$ at room temperature for $10 \mathrm{~min}$, and the biotin-labeled $\mathrm{NF}-\kappa \mathrm{B}$ probe was added for a further $20 \mathrm{~min}$. All reactions were electrophoresed on a $6 \%$ polyacrylamide gel, transferred to a positively charged 
A

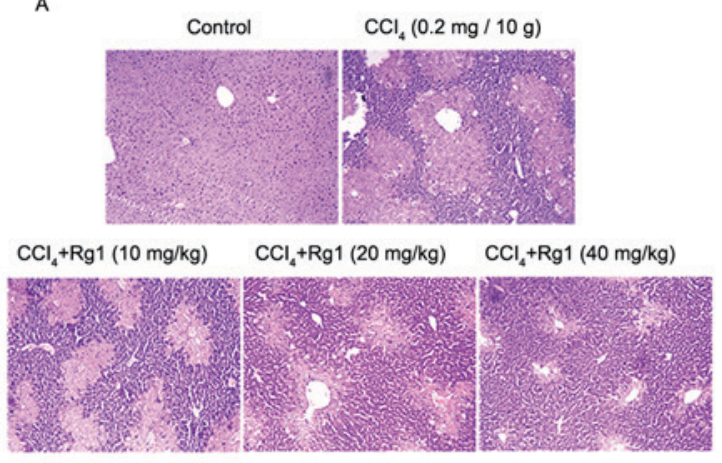

B

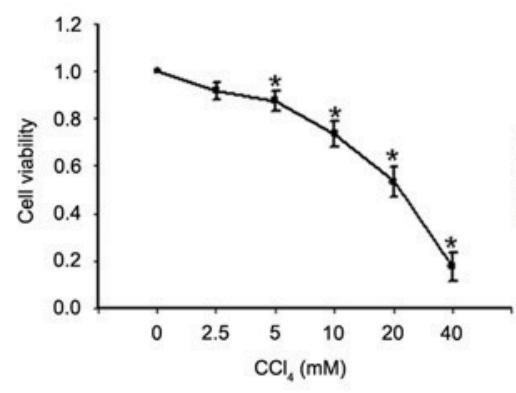

c

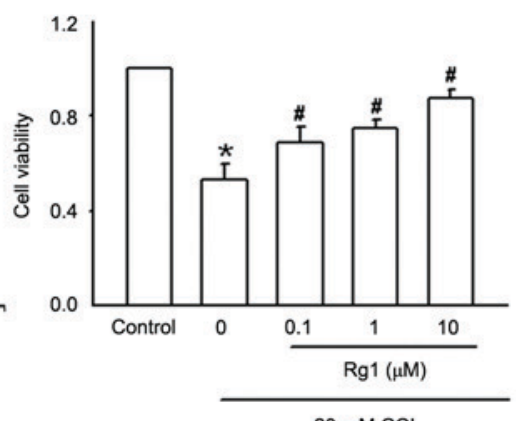

$20 \mathrm{mM} \mathrm{CCl}_{4}$

Figure 1. Protective effect of $\mathrm{Rg} 1$ on liver histopathological alterations in $\mathrm{CCl}_{4}$-induced mice and the viability of $\mathrm{CCl}_{4}$-treated $\mathrm{LO}_{2}$ cells. (A) $\mathrm{Representative}$ liver histopathology with hematoxylin/eosin staining of $\mathrm{CCl}_{4}$ induced liver injury in mice, assessed by light microscope image capture of liver sections (magnification, x100; n=8). (B) The viability of $\mathrm{LO}_{2}$ cells was assessed by MTT following treatment with $\mathrm{CCl} \mathrm{H}_{4}(2.5-40 \mathrm{mM})$ for 3 h. Data are expressed as the mean \pm standard error of the mean $(\mathrm{n}=3)$. (C) Rg1 $(0.1-10 \mu \mathrm{M})$ was added to $\mathrm{LO}_{2}$ cells for $21 \mathrm{~h}$ prior to induction with $20 \mathrm{mM} \mathrm{CCl} \mathrm{f}_{4}$ for $3 \mathrm{~h}$. Treatment with $0 \mu \mathrm{M} \mathrm{Rg} 1$ represents $\mathrm{CCl}_{4}$ group. Data are expressed as the mean \pm standard error of the mean $(\mathrm{n}=3)$. ${ }^{*} \mathrm{P}<0.05$ vs. control group, ${ }^{\sharp} \mathrm{P}<0.05$ vs. $\mathrm{CCl}{ }_{4}$ group. $\mathrm{Rg} 1$, ginsenoside $\mathrm{Rg} 1 ; \mathrm{CCl}_{4}$, carbon tetrachloride.

nylon membrane and UV cross-linked to fix the DNA. The bands were visualized by Amersham ECL ${ }^{\text {TM }}$ Plus Detection kit (GE Healthcare Bio-Sciences, Pittsburgh, PA, USA).

Western blotting. Cells were harvested using lysis buffer [20 mM Tris-HCl (pH 7.4), 150 mM NaCl, 1 mM EDTA, $1 \mathrm{mM}$ EGTA, 1\% Triton X-100, $2.5 \mathrm{mM}$ sodium pyrophosphate, $1 \mathrm{mM} \mathrm{Na}_{3} \mathrm{VO}_{4}, 1 \mathrm{mM} \beta$-glycerophosphate and 1:1,000 protease inhibitors]. Protein concentration was determined using the BCA kit then $25 \mu \mathrm{g}$ total protein from each sample was analyzed by SDS-PAGE and transferred onto a nitrocellulose membrane followed by immunoblotting. The membranes were probed with antibodies against p65 $(1: 1,000)$ and $\beta$-actin (A1978; 1:8,000; Sigma-Aldrich; Merck KGaA) and the antibodies were blocked with the primary antibody dilution (Bi Yun Tian Biotechnology Co., Ltd., Shanghai, China), at $4^{\circ} \mathrm{C}$ overnight. Then the membranes were probed by goat anti-rabbit or anti-mouse IgG antibody HRP conjugate secondary antibodies for p65 (1:2,000) and $\beta$-actin (BL003A; 1:10,000; Biosharp, Hefei, China) at room temperature for $1 \mathrm{~h}$. Immunopositive bands were visualized by Amersham ECL ${ }^{\mathrm{TM}}$ Plus Western Blotting Detection kit (RPN2232; GE Healthcare Bio-Sciences, Pittsburgh, PA, USA). The expression of p65 and $\beta$-actin as detected by western blotting were analyzed by Image J software version 1.48 (National Institutes of Health, Bethesda, MD, USA) as was the density of western blotting.

Statistical analysis. Data were processed using SPSS software (version 16; SPSS, Inc., Chicago, IL, USA). The results are expressed as the mean \pm standard error of the mean. Two-group comparisons were analyzed using an unpaired Student's $t$ test. $\mathrm{P}<0.05$ was considered to indicate a statistically significant difference. All analyses were plotted using SigmaPlot version 10.0 (Jandel Scientific, San Rafael, CA, USA).

\section{Results}

Protective effect of $\mathrm{Rgl}$ on acute $\mathrm{CCl}_{4}$-induced liver injury models. In order to characterize the function of $\mathrm{Rg} 1$ in acute $\mathrm{CCl}_{4}$-induced liver injury in mice, histopathology of liver tissues was performed using H\&E staining (Fig. 1A). The control group exhibited normal liver morphology and intact lobular architecture, neat hepatic cords, clear boundaries of liver cells and round and well-defined nuclei in the absence of inflammatory cell infiltration. In the liver of the $\mathrm{CCl}_{4}$-treated mouse presented in the second panel, normal liver tissue structure disappeared and lobular structure was disrupted, inflammatory cell infiltration was observed at lobular and portal areas, including disordered hepatic cords, and significant swelling of liver cells suggested high levels of necrosis. However, with the addition of $\mathrm{Rg} 1$, particularly for the higher dose group, liver cell degeneration and necrosis was markedly reduced, a clearer lobular structure and neatly arranged liver cells were observed, and the inflammatory cell infiltration was also reduced.

The effect of $\mathrm{Rg} 1$ on acute $\mathrm{CCl}_{4}$-induced liver injury in $\mathrm{LO}_{2}$ cells was also investigated (Fig. $1 \mathrm{~B}$ and $\mathrm{C}$ ). Increasing concentrations of $\mathrm{CCl}_{4}(2.5-40 \mathrm{mM})$ were added to $\mathrm{LO}_{2}$ cells for $3 \mathrm{~h}$, and the effect of $\mathrm{CCl}_{4}$ cytotoxicity on $\mathrm{LO}_{2}$ cells was detected by MTT assay. As presented in Fig. 1B, CCl4 led to an apparent concentration-dependent decrease in cell viability. The cell survival rates with 2.5 and $20 \mathrm{mM} \mathrm{CCl}_{4}$ were 91.23 and $53.39 \%$, respectively. When the $40 \mathrm{mM} \mathrm{CCl}_{4}$ cells were observed under the microscope, the survival rate was $20.12 \%$. A concentration of $20 \mathrm{mM} \mathrm{CCl}_{4}$ was used for the following $\mathrm{CCl}_{4}$-induced $\mathrm{LO}_{2}$ cell injury model.

The addition of $\mathrm{Rg} 1$ at a range of concentrations $(0.1-10 \mu \mathrm{M})$ to $\mathrm{LO}_{2}$ cells for $21 \mathrm{~h}$ prior to exposure to $20 \mathrm{mM} \mathrm{CCl}_{4}$, and detection of cell viability by MTT assay, demonstrated that incubation with $\mathrm{CCl}_{4}$ alone for $3 \mathrm{~h}$ decreased cell viability to $53.08 \%$; the addition of $\mathrm{Rg} 1$ markedly improved cell viability in a concentration-dependent manner. The cell survival rate of the $0.1 \mu \mathrm{M} \mathrm{Rg} 1$ group was $66.67 \%$ and the $10 \mu \mathrm{M}$ group reached $84.69 \%$ (Fig. 1C).

Effect of Rgl on ALT and AST levels in acute $\mathrm{CCl}_{4}$-induced liver injury models. The serum contents of ALT and AST presented in Table I demonstrated that, compared with levels of ALT and AST in the control group (34.54 \pm 5.63 and $75.76 \pm 7.64 \mathrm{U} / 1$, respectively), the expression levels of ALT and 
Table I. Effects of Rg1 on the serum levels of ALT and AST in mice with acute liver injury induced by $\mathrm{CCl}_{4}$ (mean \pm standard error of the mean; $n=8$ ).

\begin{tabular}{lccc}
\hline Rroups & $\begin{array}{c}\text { Rg1 dose, } \\
\text { mg/kg }\end{array}$ & ALT, U/1 & AST, U/1 \\
\hline Control & 0 & $34.54 \pm 5.63$ & $75.76 \pm 7.64$ \\
CCl $_{4}$ model & 0 & $89.90 \pm 8.18^{\mathrm{a}}$ & $182.20 \pm 8.33^{\mathrm{a}}$ \\
Rg1 (low) & 10 & $80.81 \pm 5.46$ & $169.02 \pm 7.60^{\mathrm{b}}$ \\
Rg1 (middle) & 20 & $67.25 \pm 9.21^{\mathrm{b}}$ & $148.77 \pm 5.45^{\mathrm{b}}$ \\
Rg1 (high) & 40 & $50.88 \pm 10.85^{\mathrm{b}}$ & $100.64 \pm 8.53^{\mathrm{b}}$ \\
\hline
\end{tabular}

${ }^{\mathrm{a}} \mathrm{P}<0.05$ vs. control; ${ }^{\mathrm{b}} \mathrm{P}<0.05$, vs. $\mathrm{CCl}_{4}$ model group. ALT, alanine aminotransferase; AST, aspartate aminotransferase; Rg1, ginsenoside $\mathrm{Rg} 1 ; \mathrm{CCl}_{4}$, carbon tetrachloride.

Table II. Effects of Rg1 on ALT and AST levels in supernatants of $\mathrm{CCl}_{4}$-treated $\mathrm{LO}_{2}$ cells (mean \pm standard error of the mean; $\mathrm{n}=8)$.

\begin{tabular}{lccc}
\hline Groups & $\begin{array}{c}\text { Rg1 dose, } \\
\mathrm{mg} / \mathrm{kg}\end{array}$ & ALT, U/1 & AST, U/1 \\
\hline Control & 0 & $19.35 \pm 4.82$ & $25.88 \pm 6.54$ \\
CCl $_{4}$ model & 0 & $85.88 \pm 7.55^{\mathrm{a}}$ & $128.36 \pm 9.03^{\mathrm{a}}$ \\
Rg1 (low) & 0.1 & $78.14 \pm 6.60$ & $116.04 \pm 7.91^{\mathrm{b}}$ \\
Rg1 (middle) & 1 & $52.33 \pm 8.37^{\mathrm{b}}$ & $70.07 \pm 4.96^{\mathrm{b}}$ \\
Rg1 (high) & 10 & $32.49 \pm 7.15^{\mathrm{b}}$ & $36.50 \pm 6.8^{\mathrm{b}}$ \\
\hline
\end{tabular}

${ }^{\mathrm{a}} \mathrm{P}<0.05$ vs. control; ${ }^{\mathrm{b}} \mathrm{P}<0.05$, vs. $\mathrm{CCl}_{4}$ model group. ALT, alanine aminotransferase; AST, aspartate aminotransferase; $\operatorname{Rg} 1$, ginsenoside $\mathrm{Rg} 1 ; \mathrm{CCl}_{4}$, carbon tetrachloride.

AST in $\mathrm{CCl}_{4}$-treated mice significantly increased $(89.90 \pm 8.18$ and $182.20 \pm 8.33 \mathrm{U} / 1$, respectively; $\mathrm{P}<0.05$ ). However, oral administration of $\mathrm{Rg} 1$ gradually reduced the serum levels of ALT and AST; particularly in the high-dose group $(40 \mathrm{mg} / \mathrm{kg})$, the serum ALT expression level reduced to $50.88 \pm 10.85 \mathrm{U} / 1$ and the AST expression level reduced to $100.64 \pm 8.53 \mathrm{U} / \mathrm{l}$.

ALT and AST levels in the cell culture supernatant of $\mathrm{CCl}_{4}$-treated $\mathrm{LO}_{2}$ cells were assessed following pretreatment with increasing concentrations of $\operatorname{Rg} 1(0.1-10 \mu \mathrm{M})$. Consistent with the results of ALT and AST expression levels in vivo, $20 \mathrm{mM}$ $\mathrm{CCl}_{4}$ caused a significant increase in the levels of ALT and AST, while pretreatment with Rg1 decreased ALT and AST expression levels in a concentration-dependent manner (Table II).

Effect of Rgl on SOD activity and MDA content in acute CCl4-induced liver injury models. In order to investigate the effect of Rg1 on SOD activity and MDA content in acute $\mathrm{CCl}_{4}$-induced liver injury in mice, $10 \%$ liver homogenate supernatants of the different treatment groups were prepared, and the results presented in Table III demonstrated that SOD activity in mice that were intraperitoneally injected with $\mathrm{CCl}_{4}$ was decreased $(113.21 \pm 11.31 \mathrm{U} / \mathrm{mg})$ compared with control
Table III. Effects of Rg1 on the activity of SOD and concentration of MDA in liver homogenates of $\mathrm{CCl}_{4}$-treated mice (mean \pm standard error of the mean; $n=8$ ).

\begin{tabular}{lclc}
\hline Groups & $\begin{array}{c}\text { Rg1 dose, } \\
\mathrm{mg} / \mathrm{kg}\end{array}$ & $\begin{array}{c}\text { SOD, } \\
\text { U/mgprot }\end{array}$ & $\begin{array}{c}\text { MDA, } \\
\text { nmol/mgprot }\end{array}$ \\
\hline Control & 0 & $212.31 \pm 5.65$ & $3.42 \pm 0.88$ \\
CCl $_{4}$ model & 0 & $113.21 \pm 11.31^{\mathrm{a}}$ & $8.78 \pm 0.62^{\mathrm{a}}$ \\
Rg1 (low) & 10 & $128.14 \pm 11.50^{\mathrm{b}}$ & $8.35 \pm 0.73$ \\
Rg1 (middle) & 20 & $145.61 \pm 8.27^{\mathrm{b}}$ & $7.18 \pm 0.94^{\mathrm{b}}$ \\
Rg1 (high) & 40 & $185.20 \pm 11.25^{\mathrm{b}}$ & $4.86 \pm 0.92^{\mathrm{b}}$ \\
\hline
\end{tabular}

${ }^{\mathrm{a}} \mathrm{P}<0.05$ vs. control; ${ }^{\mathrm{b}} \mathrm{P}<0.05$, vs. $\mathrm{CCl}_{4}$ model group. $\mathrm{SOD}$, superoxide dismutase; MDA, malondialdehyde; $\mathrm{Rg} 1$, ginsenoside $\mathrm{Rg} 1 ; \mathrm{CCl}_{4}$, carbon tetrachloride.

group $(212.31 \pm 5.65 \mathrm{U} / \mathrm{mg})$; however, pretreatment with $\mathrm{Rg} 1$ caused a dose-dependent enhancement of SOD activity. By contrast, the MDA expression level was increased in $\mathrm{CCl}_{4}$-treated mice $(8.78 \pm 0.62 \mathrm{nmol} / \mathrm{mg})$ compared with the control group $(3.42 \pm 0.88 \mathrm{nmol} / \mathrm{mg})$, while pretreatment with Rg1 caused a dose-dependent reduction in the MDA expression level.

SOD activity and MDA content in the cell culture supernatants of the $\mathrm{CCl}_{4}$-induced $\mathrm{LO}_{2}$ cell injury and $\mathrm{Rg} 1$ treatment groups were also examined (Table IV). $\mathrm{CCl}_{4}$ inhibited SOD activity and increased the MDA expression levels of $\mathrm{LO}_{2}$ cells; however, Rg1 alleviated the inhibited SOD activity and reduced the increased MDA level, which was consistent with the results of SOD activity and MDA content experiments in vivo.

Effect of Rg1 on NF- $\mathrm{NB}$ activity in acute $\mathrm{CCl}_{4}$-induced liver injury models. Liver Kupffer cells serve a role as a barrier to liver injury. In order to investigate whether NF- $\mathrm{KB}$ is involved in the protective effect of $\mathrm{Rg} 1$ in acute $\mathrm{CCl}_{4}$-induced liver injury in mice, liver Kupffer cells were isolated from the different treatment groups. NF- $\kappa \mathrm{B}$ p65 protein expression was determined using western blotting and NF-kB binding activity using EMSA analysis. The results of the western blotting demonstrated that NF- $\mathrm{NB}$ p 65 protein expression was significantly increased in the $\mathrm{CCl}_{4}$ model group, although pretreatment with $\operatorname{Rg} 1(10-40 \mathrm{mg} / \mathrm{kg})$ reduced the protein expression of p65 in a dose-dependent manner (Fig. 2A). Additionally, the results of the EMSA analysis demonstrated that $\mathrm{CCl}_{4}(0.2 \mathrm{mg} / 10 \mathrm{~g})$ used alone enhanced NF-kB binding activity, however, pretreatment with $\operatorname{Rg} 1$ alleviated the enhanced NF-kB binding in a dose-dependent manner (Fig. 2B).

$\mathrm{NF}-\kappa \mathrm{B}$ function in the protective effect of $\mathrm{Rg} 1$ on acute $\mathrm{CCl}_{4}$-induced liver injury was further confirmed in vitro. CAPE, an inhibitor of NF- $\mathrm{KB}$, was used and its role observed on $\mathrm{CCl}_{4}$-induced $\mathrm{LO}_{2}$ cell injury. The results of the MTT assay presented in Fig. $2 \mathrm{C}$ demonstrated that exposure of $\mathrm{LO}_{2}$ cells to $20 \mathrm{mM} \mathrm{CCl}_{4}$ for $3 \mathrm{~h}$ inhibited cell growth, and CAPE $(25 \mu \mathrm{M}$, $2 \mathrm{~h}$ ) attenuated this cell growth inhibition. P65 expression in $\mathrm{LO}_{2}$ cells treated with $\mathrm{CCl}_{4}$ alone or in combination with $\mathrm{Rg} 1$ 
Table IV. Effects of Rg1 on SOD activity and MDA concentration in supernatants from $\mathrm{LO}_{2}$ cells treated with $\mathrm{CCl}_{4}$ (mean \pm standard error of the mean; $n=8$ ).

\begin{tabular}{lcll}
\hline Groups & $\begin{array}{c}\operatorname{Rg} 1 \\
\text { concentration, } \mu \mathrm{M}\end{array}$ & $\begin{array}{c}\text { SOD, } \\
\text { U/mgprot }\end{array}$ & $\begin{array}{c}\text { MDA, nmol/ } \\
\text { mgprot }\end{array}$ \\
\hline Control & 0 & $5.24 \pm 0.353$ & $0.71 \pm 0.12$ \\
CCl $_{4}$ model & 0 & $2.01 \pm 0.246^{\mathrm{a}}$ & $1.85 \pm 0.24^{\mathrm{a}}$ \\
Rg1 (low) & 0.1 & $2.21 \pm 0.26$ & $1.66 \pm 0.16$ \\
Rg1 (middle) & 1 & $4.17 \pm 0.33^{\mathrm{b}}$ & $1.24 \pm 0.19^{\mathrm{b}}$ \\
Rg1 (high) & 10 & $4.85 \pm 0.27^{\mathrm{b}}$ & $0.88 \pm 0.12^{\mathrm{b}}$ \\
\hline
\end{tabular}

${ }^{\mathrm{a}} \mathrm{P}<0.05$ vs. control; ${ }^{\mathrm{b}} \mathrm{P}<0.05$, vs. $\mathrm{CCl}_{4}$ model group. $\mathrm{SOD}$, superoxide dismutase; MDA, malondialdehyde; $\operatorname{Rg} 1$, ginsenoside $\operatorname{Rg} 1 ; \mathrm{CCl}_{4}$, carbon tetrachloride.

Table V. Effects of CAPE on SOD activity and MDA concentration in supernatants from $\mathrm{LO}_{2}$ cells treated with $\mathrm{CCl}_{4}$ (mean \pm standard error of the mean; $n=8$ ).

\begin{tabular}{lccc}
\hline Groups & $\begin{array}{c}\text { CAPE } \\
\text { concentration, } \mu \mathrm{M}\end{array}$ & $\begin{array}{c}\text { SOD, } \\
\text { U/mgprot }\end{array}$ & $\begin{array}{c}\text { MDA, } \\
\text { nmol/mgprot }\end{array}$ \\
\hline Control & 0 & $5.24 \pm 0.353$ & $0.71 \pm 0.12$ \\
$\mathrm{CCl}_{4}$ model & 0 & $2.01 \pm 0.246^{\mathrm{a}}$ & $1.85 \pm 0.24^{\mathrm{a}}$ \\
$\mathrm{CAPE}$ & 25 & $4.96 \pm 0.31^{\mathrm{b}}$ & $0.95 \pm 0.27^{\mathrm{b}}$ \\
\hline
\end{tabular}

${ }^{\mathrm{a}} \mathrm{P}<0.05$ vs. control; ${ }^{\mathrm{b}} \mathrm{P}<0.05$, vs. $\mathrm{CCl}_{4}$ model group. CAPE, caffeic acid phenethyl ester; SOD, superoxide dismutase; MDA, malondialdehyde; $\mathrm{Rg} 1$, ginsenoside $\mathrm{Rg} 1 ; \mathrm{CCl}_{4}$, carbon tetrachloride.

was observed by western blotting. When treated with $20 \mathrm{mM}$ $\mathrm{CCl}_{4}$ for $15 \mathrm{~min}$, there was no significant alteration in $\mathrm{p} 65$ expression; however, when the incubation time was prolonged to 30 or $60 \mathrm{~min}$, the expression level increased, and $10 \mu \mathrm{M}$ Rg1 alleviated the increased p65 expression (Fig. 2D and E). The present results were also confirmed by EMSA assay. Rg1 (0.1-10 $\mu \mathrm{M})$ used alone did not affect NF- $\kappa \mathrm{B}$ binding activity; however, it significantly alleviated the enhanced binding of NF- $\kappa \mathrm{B}$ when used in combination with $\mathrm{CCl}_{4}$; the $\mathrm{NF}-\kappa \mathrm{B}$ inhibitor CAPE served a comparable role and inhibited $\mathrm{CCl}_{4}$-induced NF- $\kappa \mathrm{B}$ binding (Fig. 2F).

Mechanism of $\mathrm{NF}-\kappa \mathrm{B}$ in Rgl protective effect on acute $\mathrm{CCl}_{4}$-induced liver injury models. The results presented in Table IV demonstrated that pretreatment with Rg1 alleviated the inhibited SOD activity and reduced MDA expression level in $\mathrm{CCl}_{4}$-induced $\mathrm{LO}_{2}$ cell injury. Inhibition of $\mathrm{NF}-\kappa \mathrm{B}$ activity by CAPE demonstrated comparable results: $\mathrm{CCl}_{4}$ inhibited SOD activity and increased the MDA expression level compared with the control group; however, using $25 \mu \mathrm{M}$ CAPE for $2 \mathrm{~h}$ enhanced the inhibited SOD activity and reduced the MDA expression level (Table V). The expression levels of TNF- $\alpha$ and IL-6 in 10\% liver homogenate supernatants of the different treatment groups of mice were measured by ELISA, and it was observed that $\mathrm{CCl}_{4}$ injection
Table VI. Effects of Rg1 on serum levels of TNF- $\alpha$ and IL-6 in $\mathrm{CCl}_{4}$-induced liver injury in mice.

\begin{tabular}{lccc}
\hline & $\begin{array}{c}\text { Rg1 } \\
\text { concentration, } \\
\mu \mathrm{M}\end{array}$ & $\begin{array}{c}\text { TNF- } \alpha, \\
\mathrm{pg} / \mathrm{ml}\end{array}$ & $\begin{array}{c}\mathrm{IL}-6, \\
\mathrm{pg} / \mathrm{ml}\end{array}$ \\
\hline Groups & 0 & $18.42 \pm 3.57$ & $23.66 \pm 5.32$ \\
$\mathrm{CCl}_{4}$ model & 0 & $823.45 \pm 7.43^{\mathrm{a}}$ & $97.30 \pm 13.09^{\mathrm{a}}$ \\
$\mathrm{Rg} 1$ (low) & 10 & $81.39 \pm 14.75$ & $96.20 \pm 10.53$ \\
$\operatorname{Rg} 1$ (middle) & 20 & $68.56 \pm 11.17^{\mathrm{b}}$ & $78.75 \pm 7.17^{\mathrm{b}}$ \\
$\operatorname{Rg} 1$ (high) & 40 & $39.22 \pm 7.06^{\mathrm{b}}$ & $48.75 \pm 9.54^{\mathrm{b}}$ \\
\hline
\end{tabular}

${ }^{\mathrm{a}} \mathrm{P}<0.05$ vs. control; ${ }^{\mathrm{b}} \mathrm{P}<0.05$, vs. $\mathrm{CCl}_{4}$ model group. TNF- $\alpha$, tumor necrosis factor- $\alpha$; IL-6, interleukin-6; $\operatorname{Rg} 1$, ginsenoside $\operatorname{Rg} 1 ; \mathrm{CCl}_{4}$, carbon tetrachloride.

led to an increase in the serum levels of TNF- $\alpha$ and IL-6; however, pretreatment with $\mathrm{Rg} 1$ reduced this increase in a dose-dependent manner (Table VI).

It is well known that NF- $\kappa \mathrm{B}$ expression and activity in liver Kupffer cells may be modulated by TNF- $\alpha$, IL- 6 and other cytokines, and NF- $\kappa \mathrm{B}$ may, in turn, activate these inflammatory regulators $(26,27)$. The results of the present study, displayed in Fig. $2 \mathrm{~A}$ and $\mathrm{B}$, demonstrated that $\mathrm{CCl}_{4}$ increased NF- $\kappa \mathrm{B}$ p65 protein expression and enhanced $\mathrm{NF}-\mathrm{kB}$ binding activity, while pretreatment with $\mathrm{Rg} 1$ reduced $\mathrm{p} 65$ protein expression and alleviated the enhanced $\mathrm{NF}-\kappa \mathrm{B}$ binding. Therefore, $\mathrm{Rg} 1$ protected $\mathrm{CCl}_{4}$-induced liver injury, by directly alleviating the inhibition of SOD activity and reducing MDA, and possibly by inhibiting $\mathrm{NF}-\kappa \mathrm{B}$ activity, thereby further alleviating the inhibited SOD activity and reducing MDA, TNF- $\alpha$ and IL-6 expression levels.

\section{Discussion}

The present study demonstrated that pretreatment with $\mathrm{Rg} 1$ protected the liver from $\mathrm{CCl}_{4}$-induced acute injury in cell culture and animal experimental systems. It was observed that pretreatment with $\operatorname{Rg} 1$ attenuated the pathological damage to liver tissues in vivo and $\mathrm{LO}_{2}$ cell death in vitro. The indicative enzymes of liver cell damage, serum transaminases ALT and AST, were markedly increased in the $\mathrm{CCl}_{4}$ treatment model group and decreased in the Rg1 pretreatment group. Further investigations into the antioxidant properties of $\mathrm{Rg} 1$ in acute $\mathrm{CCl}_{4}$-induced liver injury demonstrated that SOD activity was inhibited in the $\mathrm{CCl}_{4}$ treatment group, and recovered in the Rg1 pretreatment group; MDA level was increased by treatment with $\mathrm{CCl}_{4}$ and attenuated by pretreatment with Rg1. Inflammatory cytokines TNF- $\alpha$ and IL-6, which were enhanced by $\mathrm{CCl}_{4}$ treatment, were attenuated in the $\mathrm{Rg} 1$ pretreatment group. Rg1 inhibited p65 expression and $\mathrm{NF}-\kappa \mathrm{B}$ activity in vivo and in vitro, and $\mathrm{NF}-\kappa \mathrm{B}$ inhibitor CAPE, which was observed to exhibit comparable effects, enhanced SOD activity, reduced MDA level and promoted $\mathrm{LO}_{2}$ cell survival. As NF- $\kappa$ B serves a role in the activation of inflammatory cytokines, it was hypothesized that $\mathrm{Rg} 1$ protected $\mathrm{CCl}_{4}$-induced liver injury by directly alleviating the inhibition of SOD activity and reducing MDA, and additionally by inhibiting 

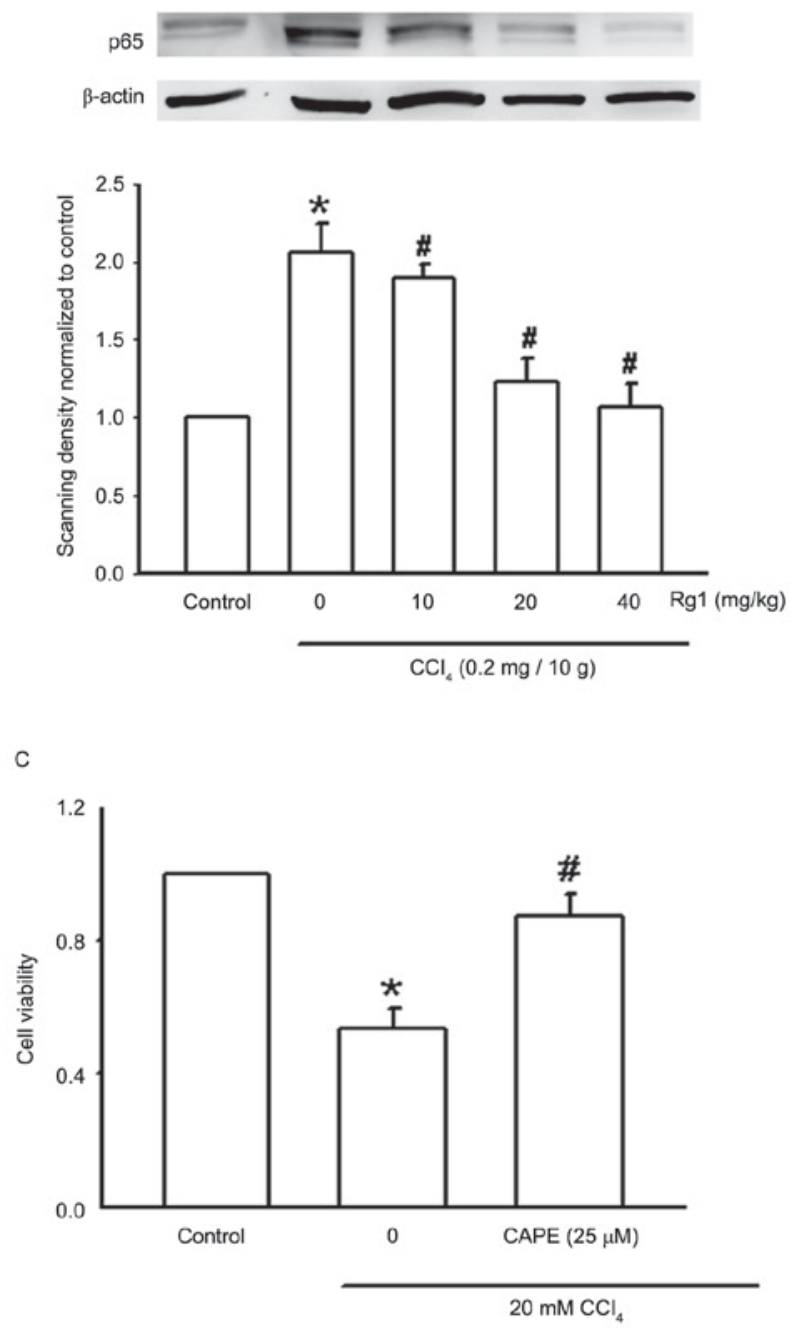

$\mathrm{E}$

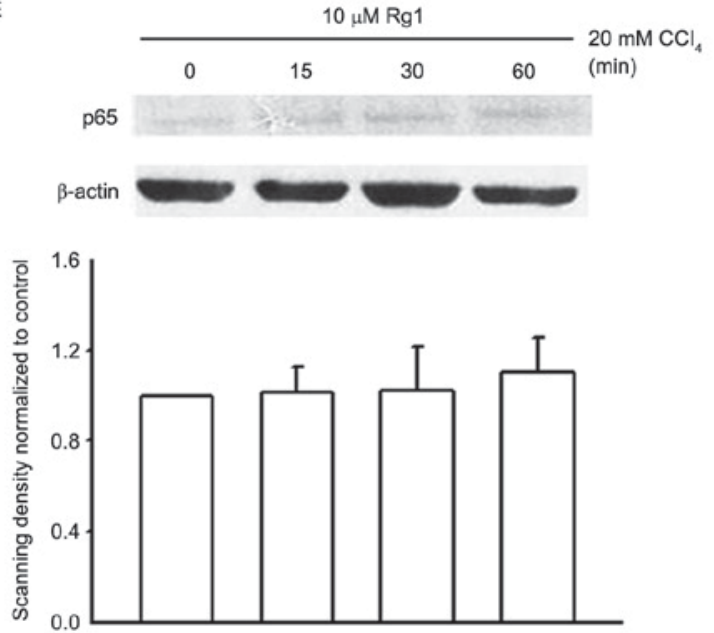

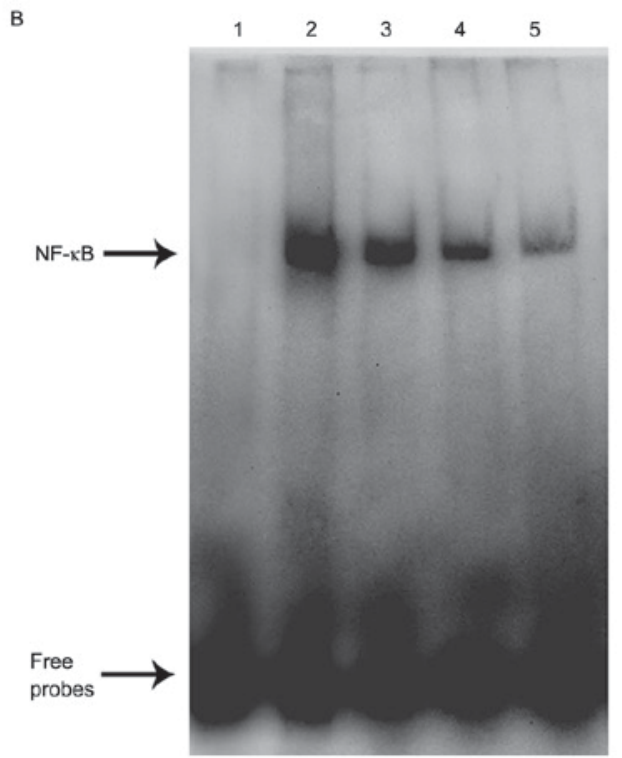

D
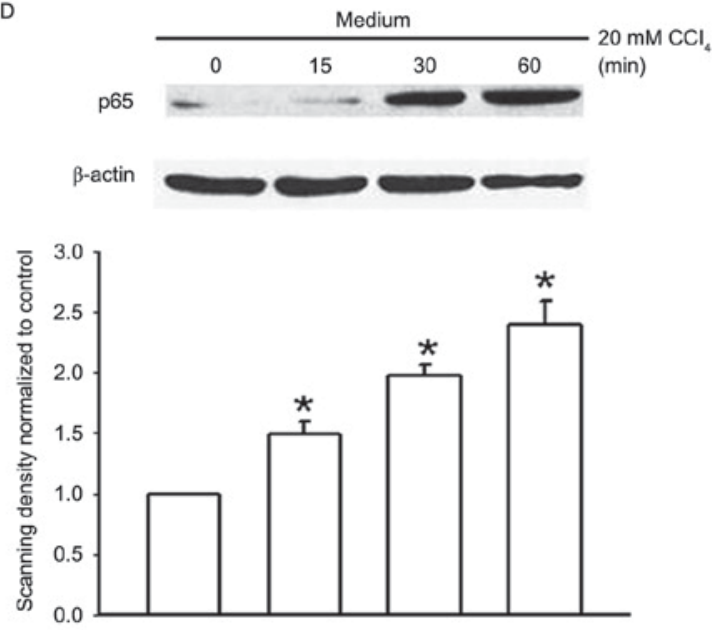

$\mathrm{F}$

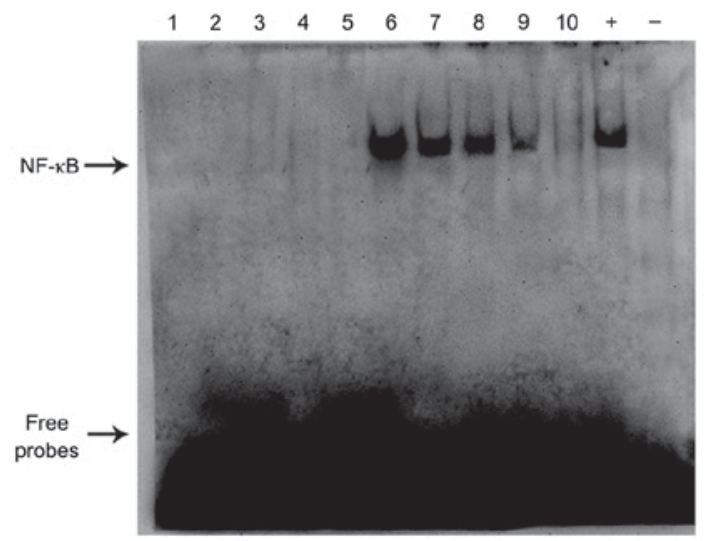

Figure 2. Expression and binding activity of NF- $\mathrm{KB}$ in the Kupffer cells of mice with $\mathrm{CCl}_{4}$-induced liver injury and $\mathrm{CCl}_{4}$-treated $\mathrm{LO}_{2}$ cells. (A) Representative images of NF- $\mathrm{KB}$ P65 protein expression assessed by western blotting in Kupffer cells isolated from mice treated with $\mathrm{CCl}_{4}$ and/or $\mathrm{Rg} 1(\mathrm{n}=4)$. (B) Representative image of NF- $\mathrm{KB}$ binding activity assessed by EMSA in the Kupffer cells of acute liver injury mice pretreated with $\operatorname{Rg} 1$ ( $\mathrm{n}=4$ ). Lane 1, control group; lane 2 , $\mathrm{CCl}_{4}$ group; lane 3, $\mathrm{CCl}_{4}+\mathrm{Rg} 1(10 \mathrm{mg} / \mathrm{kg})$; lane 4, $\mathrm{CCl}_{4}+\mathrm{Rg} 1(20 \mathrm{mg} / \mathrm{kg}) ;$ lane 5, $\mathrm{CCl}_{4}+\mathrm{Rg} 1(40 \mathrm{mg} / \mathrm{kg})$. (C) The function of the NF- $\mathrm{kB}$ inhibitor CAPE $(25 \mu \mathrm{M}, 2 \mathrm{~h})$ in $\mathrm{CCl}_{4}$-treated $\mathrm{LO}_{2}$ cells was assessed by MTT assay. The data are expressed as the mean \pm standard error of the mean (n=3). (D) Representative images of NF- $\mathrm{kB}$ P65 protein expression assessed by western-blotting in lysates from $\mathrm{LO}_{2}$ cells treatment with $\mathrm{CCl}_{4}(\mathrm{n}=3$ ). (E) Representative images of NF- $\mathrm{kB}$ P65 protein expression assessed by western-blotting in lysates from $\mathrm{LO}_{2}$ cells treatment with $10 \mu \mathrm{M} \mathrm{Rg} 1(\mathrm{n}=3)$. (F) Representative image of NF- $\mathrm{kB}$ binding activity assessed by EMSA in $\mathrm{CCl}_{4}$-treated $\mathrm{LO}_{2}$ cells (n=3). Lane 1, probe without nucleoprotein; lane 2 control group; lane $3, \operatorname{Rg} 1(0.1 \mu \mathrm{M}) ; \operatorname{lane} 4, \operatorname{Rg} 1(1 \mu \mathrm{M})$; lane 5, $\operatorname{Rg} 1(10 \mu \mathrm{M}) ;$ lane 6, $\mathrm{CCl}_{4}$ group; lane 7, $\mathrm{CCl}_{4}+\operatorname{Rg} 1(0.1 \mu \mathrm{M}) ;$ lane $8, \mathrm{CCl}_{4}+\operatorname{Rg} 1(1 \mu \mathrm{M}) ;$ lane $9, \mathrm{CCl}_{4}+\operatorname{Rg} 1(10 \mu \mathrm{M})$; lane 10, CAPE $(25 \mu \mathrm{M}) ;+, \operatorname{positive}$ control $(20 \mathrm{ng} / \mathrm{ml}$ tumor necrosis factor- $\alpha$ stimulation for $30 \mathrm{~min}) ;-$, negative control (untreated $\mathrm{LO}_{2}$ cells). ${ }^{~} \mathrm{P}<0.05$ vs. control group, ${ }^{\prime \prime} \mathrm{P}<0.05$ vs. $\mathrm{CCl} \mathrm{l}_{4}$ group. CAPE, caffeic acid phenethyl ester; $\mathrm{Rg} 1$, ginsenoside $\mathrm{Rg} 1 ; \mathrm{CCl}_{4}$, carbon tetrachloride; $\mathrm{NF}-\mathrm{\kappa B}$, nuclear factor-kB; EMSA, electrophoretic mobility shift assay. 
$\mathrm{NF}-\kappa \mathrm{B}$ activity, thereby further alleviating the inhibited SOD activity and reducing MDA, TNF- $\alpha$ and IL- 6 expression levels.

As a common pathological state of various types of liver disease, liver injury may be caused by ischemia, viral infection, autoimmune disorders and various xenobiotic substances, including alcohol, drugs and toxins (28). The present study used a $\mathrm{CCl}_{4}$-induced acute liver injury model, and this type of liver injury model is widely used in hepatoprotective drug screening $(29,30)$. The characteristics of the acute liver injury induced by $\mathrm{CCl}_{4}$ are liver dysfunction and cell morphology deterioration (31); therefore, alterations in histopathology and liver function were investigated, and it was observed that pretreatment with Rg1 attenuated the pathological damage to liver tissues and $\mathrm{LO}_{2}$ cell death. In addition, increased levels of ALT and AST expression caused by $\mathrm{CCl}_{4}$ in animal experimental systems and cell culture, which are direct hepatic functional indicators and have been demonstrated to correlate with the severity of liver injury (32), were markedly reduced by pretreatment with Rg1. The results of the present study demonstrated that pretreatment with $\mathrm{Rg} 1$ decreased hepatic dysfunction and cell morphology deterioration induced by $\mathrm{CCl}_{4}$.

Oxidative stress is considered to serve an important role in the development of $\mathrm{CCl}_{4}$-induced acute liver injury $(33,34)$. When $\mathrm{CCl}_{4}$ enters the liver and is activated by cytochrome P450 metabolism, it generates various free radicals and reactive oxygen species for oxidative stress and causes membrane lipid peroxidation $(14,15)$. The activity of SOD, an effective metalloenzyme which catalyzes the dismutation of superoxide anions into $\mathrm{H}_{2} \mathrm{O}_{2}$ and $\mathrm{O}_{2}$ (35-37), was markedly increased compared with the injury group. The studies of Zhang et al (31) and Li C (22), demonstrated that the expression level of MDA was associated with $\mathrm{CCl}_{4}$-induced acute liver injury in mice; increased expression of MDA, a lipid peroxidative product of cell membranes (38), was prevented by pretreatment with Rg1 in the present study. The hepatoprotective effect of $\mathrm{Rg} 1$ may be partly due to attenuation of oxidative stress and inhibition of lipid peroxidation.

Kupffer cells, as tissue macrophages, reside within the liver sinusoid and serve a role in homeostatic liver regeneration and protection (39-41). Activated Kupffer cells mediate the hepatic inflammation process by releasing a wide range of cytokines, including TNF- $\alpha$ and IL-6 (42). A previous study reported that $\mathrm{NF}-\kappa \mathrm{B}$ is sensitive to redox status in abnormal physiological conditions, including $\mathrm{CCl}_{4}$-induced acute liver injury (43). Additionally, the study of Tao et al (12) demonstrated that pretreatment with $\mathrm{Rg} 1$ inhibited the inflammatory response and protected the mouse liver against ischemia-reperfusion injury, partly through the $\mathrm{NF}-\kappa \mathrm{B}$ signaling pathway. The present study demonstrated that pretreatment with $\operatorname{Rg} 1$ inhibited NF- $\mathrm{\kappa B}$ activity and p65 expression in Kupffer cells and reduced the serum levels of TNF- $\alpha$ and IL- 6 in acute $\mathrm{CCl}_{4}$-induced liver injury in mice. As $\mathrm{NF}-\kappa \mathrm{B}$ expression and activity in liver Kupffer cells may be modulated by TNF- $\alpha$, IL-6 and other cytokines, and NF- $\kappa \mathrm{B}$ may, in turn, activate these inflammatory regulators, it is hypothesized that the protective effect of $\mathrm{Rg} 1$ on $\mathrm{CCl}_{4}$-induced liver injury was partly involved in the attenuation of inflammatory responses expressed as a reduction of serum TNF- $\alpha$ and IL-6 levels via the NF- $\kappa \mathrm{B}$ signaling pathway.

$\mathrm{NF}-\kappa \mathrm{B}$ was first identified as a transcription factor in 1986 by Sen and Baltimore (44). In an inactive state, $N F-\kappa B$ is sequestered in the cytoplasm as a heterotrimer consisting of $\mathrm{p} 50, \mathrm{p} 65$, and inhibitor of $\mathrm{NF}-\kappa \mathrm{B}(\mathrm{I} \kappa \mathrm{B})$ subunits. On activation, $\mathrm{I} \kappa \mathrm{B} \alpha$ undergoes phosphorylation and ubiquitination-dependent degradation leading to p65 nuclear translocation and binding to a specific consensus sequence in the DNA, which results in gene transcription. The nuclear translocation of $N F-\kappa B$ leads to gene expression of prostaglandin $\mathrm{G} / \mathrm{H}$ synthase 2 , inducible nitric oxide synthase, chemokines, adhesion molecules, matrix metalloproteinases and various pro-inflammatory cytokines $(45,46)$. These released inflammatory factors subsequently activate further amplification of $\mathrm{NF}-\kappa \mathrm{B}$ activity in a regulatory cycle. As a result, the oxidative stress in injury liver activates $N F-\kappa B$, triggering expression of oxidative stress-responsive genes, which ultimately leads to liver cell necrosis and apoptosis (47-49). The present study demonstrated that Rg1 inhibited p65 expression and $\mathrm{NF}-\kappa \mathrm{B}$ activity, in vivo and in vitro. The $\mathrm{NF}-\kappa \mathrm{B}$ inhibitor CAPE, which was confirmed to exhibit a similar effect compared with Rg1, enhanced SOD activity and reduced the MDA expression level in addition to promoting $\mathrm{LO}_{2}$ cell survival. Therefore, the possible underlying mechanisms of the beneficial effect of Rg1 may be attributed to an attenuation of the inflammatory response and oxidative stress in $\mathrm{CCl}_{4}$-induced acute liver injury via inhibition of NF-kB.

In conclusion, the present study reveals the potential clinical value of $\mathrm{Rg} 1$, and demonstrates that pretreatment with $\mathrm{Rg} 1$ may protect against $\mathrm{CCl}_{4}$-induced acute hepatotoxicity in vivo and in vitro, via inhibition of $\mathrm{NF}-\kappa \mathrm{B}$ activity to restore the anti-oxidative defense system and downregulate pro-inflammatory signaling pathways.

\section{Acknowledgements}

The present study was supported by the National Natural Science Foundation of Anhui (grant no. 1508085QH151), the Natural Science Foundation of the Provincial Education Department of Anhui (grant no. KJ2015A147), the National Natural Science Foundation of China (grant no. 81001457) and the Foundation of Bengbu Medical College (grant nos. Byycxz1422 and Byky1407ZD).

\section{References}

1. Protzer U, Maini MK and Knolle PA: Living in the liver: Hepatic infections. Nat Rev Immunol 12: 201-213, 2012.

2. Duarte S, Baber J, Fujii T and Coito AJ: Matrix metalloproteinases in liver injury, repair and fibrosis. Matrix Biol 44-46: 147-156, 2015.

3. Bengmark S: Curcumin an atoxic antioxidant and natural NFkappaB, cyclooxygenase-2, lipooxygenase, and inducible nitric oxide synthase inhibitor: A shield against acute and chronic diseases. JPEN J Parenter Enteral Nutr 30: 45-51, 2006.

4. Williams R: Global challenges in liver disease. Hepatology 44: 521-526, 2006.

5. Stickel F and Schuppan D: Herbal medicine in the treatment of liver diseases. Dig Liver Dis 39: 293-304, 2007.

6. Ghosh N, Ghosh R, Mandal V and Mandal S: Recent advances in herbal medicine for treatment of liver diseases. Pharm Biol 49: 970-988, 2001.

7. Attele AS, Wu JA and Yuan CS: Ginseng pharmacology: Multiple constituents and multiple actions. Biochem Pharmacol 58: 1685-1693, 1999.

8. Li QF, Shi SL, Liu QR, Tang J, Song J and Liang Y: Anticancer effects of ginsenoside Rg1, cinnamic acid, and tanshinone IIA in osteosarcoma MG-63 cells: Nuclear matrix downregulation and cytoplasmic trafficking of nucleophosmin. Int J Biochem Cell Biol 40: 1918-1929, 2008. 
9. Liu Q, Kou JP and Yu BY: Ginsenoside Rg1 protects against hydrogen peroxide-induced cell death in PC12 cells via inhibiting NF- $\mathrm{KB}$ activation. Neurochem Int 58: 119-125, 2011.

10. Komatsu K, Tanaka H, Nakagawa D and Kawashima K: Effect of notoginseng extracts and their components on lipopolysaccharide and galactosamine mixture-induced impaired hepatic function in mice. Yakugaku Zasshi 132: 831-836, 2012 (In Japanese).

11. Cao L, Zou Y, Zhu J, Fan X and Li J: Ginsenoside Rg1 attenuates concanavalin A-induced hepatitis in mice through inhibition of cytokine secretion and lymphocyte infiltration. Mol Cell Biochem 380: 203-210, 2013.

12. Tao T, Chen F, Bo L, Xie Q, Yi W, Zou Y, Hu B, Li J and Deng X: Ginsenoside Rg1 protects mouse liver against ischemia-reperfusion injury through anti-inflammatory and anti-apoptosis properties. J Surg Res 191: 231-238, 2014.

13. Hines IN and Wheeler MD: Recent advances in alcoholic liver disease III. Role of the innate immune response in alcoholic hepatitis. Am J Physiol Gastrointest Liver Physiol 287: G310-G314, 2004.

14. LeSage GD, Benedetti A, Glaser S, Marucci L, Tretjak Z, Caligiuri A, Rodgers R, Phinizy JL, Baiocchi L, Francis H, et al: Acute carbon tetrachloride feeding selectively damages large, but not small, cholangiocytes from normal rat liver. Hepatology 29: 307-319, 1999

15. Shiga A, Kakamu S, Sugiyama Y, Shibata M, Makino E and Enomoto M: Acute toxicity of pierisin-1, a cytotoxic protein from Pieris rapae, in mouse and rat. J Toxicol Sci 31: 123-137, 2006.

16. Baldwin AS Jr: The NF-kappa B and I kappa B proteins: New discoveries and insights. Annu Rev Immunol 14: 649-683, 1996.

17. Harada N, Iimuro Y, Nitta T, Yoshida M, Uchinami H, Nishio T, Hatano E, Yamamoto N, Yamamoto $\mathrm{Y}$ and Yamaoka $\mathrm{Y}$ : Inactivation of the small GTPase Racl protects the liver from ischemia/reperfusion injury in the rat. Surgery 134: 480-491, 2003.

18. Son G, Iimuro Y, Seki E, Hirano T, Kaneda Y and Fujimoto J: Selective inactivation of NF-kappaB in the liver using NF-kappaB decoy suppresses CCl4-induced liver injury and fibrosis. Am J Physiol Gastrointest Liver Physiol 293: G631-G639, 2007.

19. Suetsugu H, Iimuro $Y$, Uehara T, Nishio T, Harada N, Yoshida M, Hatano E, Son G, Fujimoto J and Yamaoka Y: Nuclear factor $\{$ kappa\}B inactivation in the rat liver ameliorates short term total warm ischaemia/reperfusion injury. Gut 54: 835-842, 2005.

20. Veal N, Hsieh CL, Xiong S, Mato JM, Lu S and Tsukamoto $\mathrm{H}$ : Inhibition of lipopolysaccharide-stimulated TNF-alpha promoter activity by S-adenosylmethionine and 5'-methylthioadenosine. Am J Physiol Gastrointest Liver Physiol 287: G352-G362, 2004.

21. Uesugi T, Froh M, Arteel GE, Bradford BU, Gäbele E, Wheeler MD and Thurman RG: Delivery of IkappaB superrepressor gene with adenovirus reduces early alcohol-induced liver injury in rats. Hepatology 34: 1149-1157, 2001.

22. Li C, Yi LT, Geng D, Han YY and Weng LJ: Hepatoprotective effect of ethanol extract from Berchemia lineate against CCL4-induced acute hepatotoxicity in mice. Pharm Biol 53: 767-772, 2015

23. Fukada H, Yamashina S, Izumi K, Komatsu M, Tanaka K, Ikejima $\mathrm{K}$ and Watanabe $\mathrm{S}$ : Suppression of autophagy sensitizes kupffer cells to endotoxin. Hepatol Res 42: 1112-1118, 2012.

24. Smedsrød B and Pertoft H: Preparation of pure hepatocytes and reticuloendothelial cells in high yield from a single rat liver by means of Percoll centrifugation and selective adherence. J Leukoc Biol 38: 213-230, 1985.

25. Li L, Wang Y, Qi B, Yuan D, Dong S, Guo D, Zhang C and Yu M: Suppression of PMA-induced tumor cell invasion and migration by ginsenoside $\mathrm{Rg} 1$ via the inhibition of NF- $\mathrm{KB}$-dependent MMP-9 expression. Oncol Rep 32: 1779-1786, 2014.

26. Kunsch C and Medford RM: Oxidative stress as a regulator of gene expression in the vasculature. Circ Res 85: 753-766, 1999.

27. Parola M and Robino G: Oxidative stress-related molecules and liver fibrosis. J Hepatol 35: 297-306, 2001

28. Kondo T, Suda T, Fukuyama H, Adachi M and Nagata S: Essential roles of the Fas ligand in the development of hepatitis Nat Med 3: 409-413, 1997.

29. Streetz KL, Wüstefeld T, Klein C, Manns MP and Trautwein C: Mediators of inflammation and acute phase response in the liver. Cell Mol Biol (Noisy-le-grand) 47: 661-673, 2001.
30. Masuda Y: Learning toxicology from carbon tetrachloride-induced hepatotoxicity. Yakugaku Zasshi 126: 885-899, 2006 (In Japanese).

31. Zhang F, Wang X, Qiu X, Wang J, Fang H, Wang Z, Sun Y and Xia Z: The protective effect of Esculentoside A on experimental acute liver injury in mice. PLoS One 9: e113107, 2014

32. Ozer J, Ratner M, Shaw M, Bailey W and Schomaker S: The current state of serum biomarkers of hepatotoxicity. Toxicology 245: 194-205, 2008.

33. Sun F, Hamagawa E, Tsutsui C, Ono Y, Ogiri Y and Kojo S: Evaluation of oxidative stress during apoptosis and necrosis caused by carbon tetrachloride in rat liver. Biochim Biophys Acta 1535: 186-191, 2001.

34. Weber LW, Boll M and Stampfl A: Hepatotoxicity and mechanism of action of haloalkanes: Carbon tetrachloride as a toxicological model. Crit Rev Toxicol 33: 105-136, 2003.

35. Reiter RJ, Tan DX, Osuna C and Gitto E: Actions of melatonin in the reduction of oxidative stress. A review. J Biomed Sci 7: 444-458, 2000

36. Cheng N, Ren N, Gao H, Lei X, Zheng J and Cao W: Antioxidant and hepatoprotective effects of Schisandra chinensis pollen extract on CCl4-induced acute liver damage in mice. Food Chem Toxicol 55: 234-240, 2013.

37. Ai G, Liu Q, Hua W, Huang Z and Wang D: Hepatoprotective evaluation of the total flavonoids extracted from flowers of Abelmoschus manihot (L.) Medic: In vitro and in vivo studies. J Ethnopharmacol 146: 794-802, 2013.

38. Montanari RM, Barbosa LC, Demuner AJ, Silva CJ, Andrade NJ, Ismail FM and Barbosa MC: Exposure to Anacardiaceae volatile oils and their constituents induces lipid peroxidation within food-borne bacteria cells. Molecules 17: 9728-9740, 2012.

39. Tsutsui $H$ and Nishiguchi S: Importance of Kupffer cells in the development of acute liver injuries in mice. Int J Mol Sci 15: 7711-7730, 2014

40. Meijer C, Wiezer MJ, Diehl AM, Schouten HJ, Schouten HJ, Meijer S, van Rooijen N, van Lambalgen AA, Dijkstra CD and van Leeuwen PA: Kupffer cell depletion by CI2MDP-liposomes alters hepatic cytokine expression and delays liver regeneration after partial hepatectomy. Liver 20: 66-77, 2000.

41. Seki E, Tsutsui H, Iimuro Y, Naka T, Son G, Akira S, Kishimoto T, Nakanishi K and Fujimoto J: Contribution of Toll-like receptor/myeloid differentiation factor 88 signaling to murine liver regeneration. Hepatology 41: 443-450, 2005.

42. Akamatsu K, Yamasaki Y, Nishikawa M, Takakura Y and Hashida M: Synthesis and pharmacological activity of a novel water-soluble hepatocyte-specific polymeric prodrug of prostaglandin $\mathrm{E}(1)$ using lactosylated poly(L-glutamic hydrazide) as a carrier. Biochem Pharmacol 62: 1531-1536, 2001.

43. Ko JH and Lim KT: Glycoprotein isolated from Ulmus davidiana NAKAI protects against carbon tetrachloride-induced liver injury in the mouse. J Pharmacol Sci 101: 205-213, 2006.

44. Sen R and Baltimore D: Inducibility of kappa immunoglobulin enhancer-binding protein Nf-kappa B by a posttranslational mechanism. Cell 47: 921-928, 1986.

45. Baeuerle PA and Baichwal VR: NF-kappa B as a frequent target for immunosuppressive and anti-inflammatory molecules. Adv Immunol 65: 111-137, 1997.

46. Nanji AA, Jokelainen K, Rahemtulla A, Miao L, Fogt F, Matsumoto H, Tahan SR and Su GL: Activation of nuclear factor kappa B and cytokine imbalance in experimental alcoholic liver disease in the rat. Hepatology 30: 934-943, 1999.

47. Tacchini L, Pogliaghi G, Radice L, Anzon E and Bernelli-Zazzera A: Differential activation of heat-shock and oxidation-specific stress genes in chemically induced oxidative stress. Biochem J 309: 453-459, 1995.

48. Kim WH, Hong F, Jaruga B, Hu Z, Fan S, Liang TJ and Gao B: Additive activation of hepatic NF-kappaB by ethanol and hepatitis B protein X (HBX) or HCV core protein: Involvement of TNF-alpha receptor 1-independent and -dependent mechanisms. FASEB J 15: 2551-2553, 2001.

49. De Lucca FL, Serrano SV, Souza LR and Watanabe MA: Activation of RNA-dependent protein kinase and nuclear factor-kB by regulatory RNA from lipopolysaccharide-stimulated macrophages: Implications for cytokine production. Eur J Pharmacol 450: 85-89, 2002 